\title{
Palamedes Swallowtail, Laurel Swallowtail, Papilio palamedes (Drury) (Insecta: Lepidoptera: Papilionidae) ${ }^{1}$
}

Donald W. Hall ${ }^{2}$

\section{Introduction}

The palamedes swallowtail is a large, dark swallowtail butterfly marked with yellow spots and bands. It is particularly common in and near swampy woods.

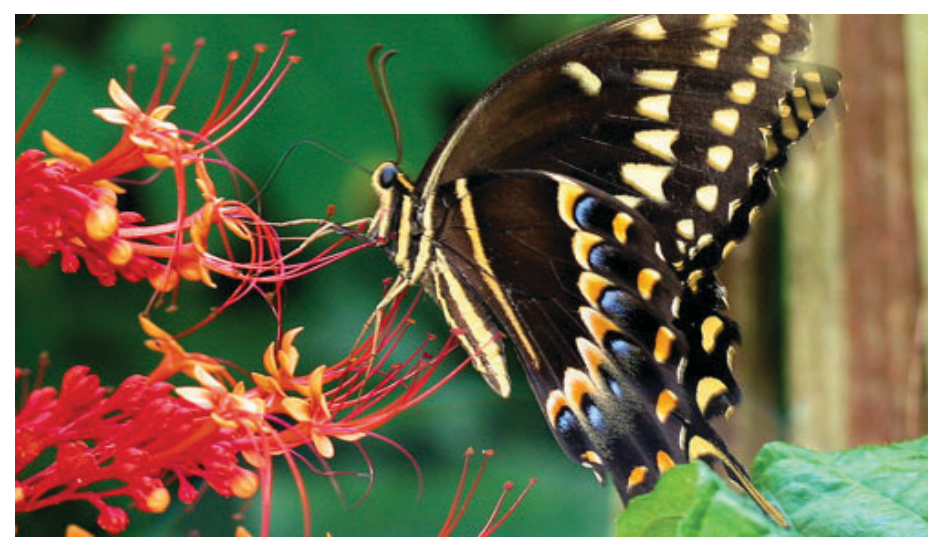

Figure 1. Palamedes swallowtail, Papilio palamedes (Drury) sipping nectar from a pagoda flower, Clerodendrum paniculatum L.

Credits: Donald W. Hall, UF/IFAS

\section{Nomenclature}

Linnaeus grouped some swallowtails and other butterflies under the genus name Papilio and used the names of heroes of the Trojan War as specific epithets (Tyler 1975). Papilio is the Latin word for butterfly. Palamedes is a character of Greek mythology (Opler and Krizek 1984).

There is disagreement on the generic classification of the swallowtails (Hancock 1983; Miller 1987). Some authors (e.g., Tyler et al. 1994; Minno et al. 2005; Warren et al. 2016) follow the system that elevates the subgenus Pterourus to generic status as proposed by Hancock (1983). The subgenus name Pterourus is from the Greek roots "ptero" for wing and "ura" for tail (Borror 1960). However, Miller (1987) argued that there is insufficient evidence to support elevation of the Papilio subgenera to genera. Because the name Papilio is still so widely used in many sources available to the public, it will be used here instead of Pterourus for practical reasons.

Drury (1770-1782) described and illustrated Papilio palamedes. There are two named subspecies. Subspecies palamedes is found in the United States. Subspecies leontis (Rothschild and Jordan 1906) is found in northeastern Mexico (Warren et al. 2016). Only subspecies palamedes will be considered here.

\section{Synonymy}

Tyler et al. (1994), Heppner (2003) and Pelham (2008) listed the following synonyms:

- Papilio chalcas (Fabricius 1775)

- Papilio flavomaculatus (Goeze 1779)

Scudder (1889) used the genus name Euphoeades (Hübner) and listed Papilio palamedes as a synonym. In addition to

1. This document is EENY-060, one of a series of the Department of Entomology and Nematology, UF/IFAS Extension. Original publication date August 1998. Revised August 2010, August 2013, August 2016, and January 2018. Visit the EDIS website at http://edis.ifas.ufl.edu. This document is also available on the Featured Creatures website at http://entnemdept.ifas.ufl.edu/creatures/.

2. Donald W. Hall, professor, Department of Entomology and Nematology; UF/IFAS Extension, Gainesville, FL 32611.

The Institute of Food and Agricultural Sciences (IFAS) is an Equal Opportunity Institution authorized to provide research, educational information and other services only to individuals and institutions that function with non-discrimination with respect to race, creed, color, religion, age, disability, sex, sexual orientation, marital status, national origin, political opinions or affiliations. For more information on obtaining other UF/IFAS Extension publications, contact your county's UF/IFAS Extension office. 
the synonyms listed above, Scudder also listed the following synonyms:

- Euphoeades chalcas Hübner

- Princeps heroicas chalcas Hübner

\section{Distribution}

The Palamedes swallowtail is found in the coastal plains of the southeastern states from southeast Virginia to Louisiana and Texas and all of mainland Florida (Figure 2). Strays have been found outside the year-round range as far west as Nebraska and as far north as New York (Butterflies and Moths of North America 2017). The Palamedes swallowtail is rare in the Florida Keys, and records from the Keys are considered to be of strays from the mainland (Minno and Emmel 1993).

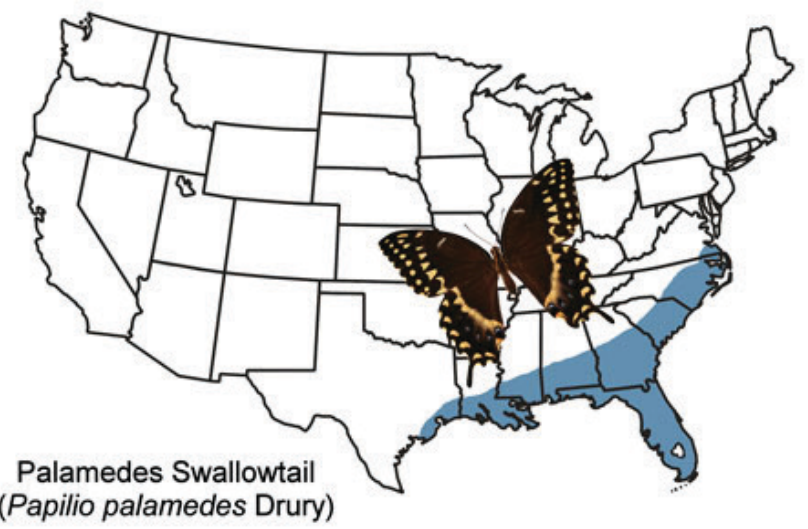

Figure 2. Palamedes swallowtail, Papilio palamedes (Drury), US yearround distribution.

Credits: Donald W. Hall, UF/IFAS

\section{Description}

\section{Adults}

The wingspread is $11.2-13.2 \mathrm{~cm}(4.4-5.2 \mathrm{in})$ (Opler and Malikul 1998). The sexes are similar in appearance. The upper surface of the wings is brownish-black with yellow markings. The front wing has a double row of yellow spots on the distal one third and a row of small, yellow spots on the margin. The upper side of the hind wing has a marginal row of yellow spots and an uninterrupted sub-marginal yellow band (Figure 3 ). The tails may have a yellow stripe down the middle. The abdomen has broad yellow longitudinal stripes.

Male black swallowtails, Papilio polyxenes Fabricius, are similar, but smaller, the hindwing sub-marginal yellow band is interrupted by black wing veins, and the abdomen has longitudinal rows of yellow spots instead of stripes.
The underside of the hind wing has a distinctive basal yellow line that runs parallel to the body (Figure 4).

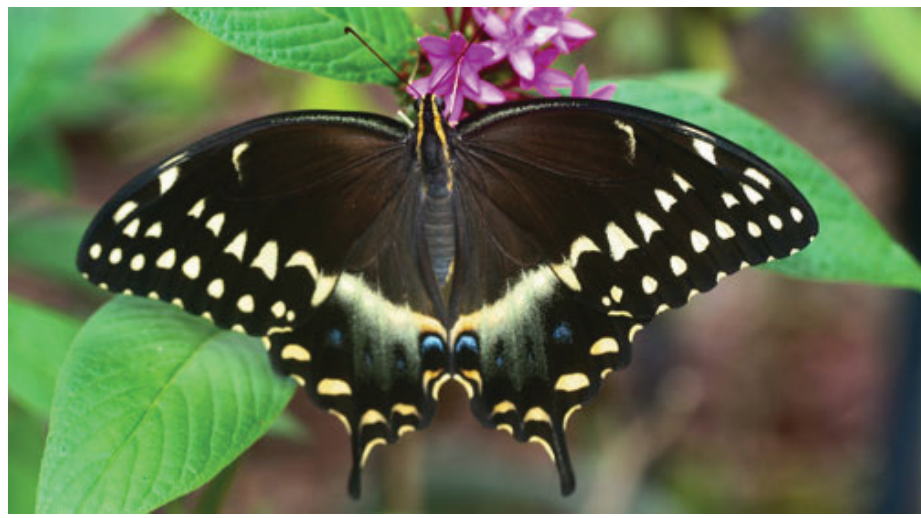

Figure 3. Palamedes swallowtail, Papilio palamedes (Drury) posed on Egyptian starcluster, Pentas lanceolata (Forssk.) Deflers.

Credits: Donald W. Hall, UF/IFAS

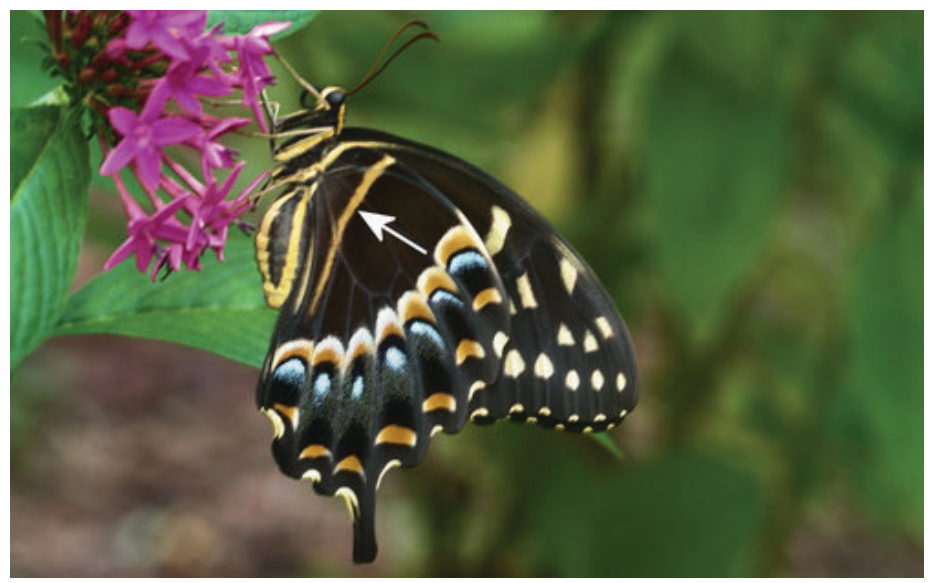

Figure 4. Palamedes swallowtail, Papilio palamedes (Drury), posed on Egyptian starcluster, Pentas lanceolata (Forssk.) Deflers. Note characteristic hind wing basal yellow line (arrow). Credits: Donald W. Hall, UF/IFAS

\section{Eggs}

Eggs are pale greenish-white (Figure 5).

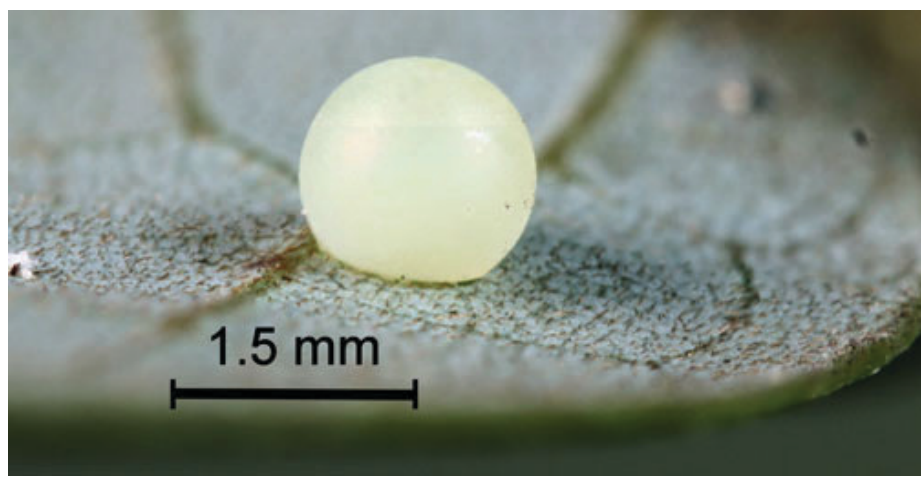

Figure 5. Palamedes swallowtail, Papilio palamedes (Drury), egg. Credits: Donald W. Hall, UF/IFAS 


\section{Larvae}

Full-grown larvae (5th instars) are approximately six centimeters (2.4 inches) in length (Minno et al. 2005). They are green with a pale yellow lateral line edged beneath with a fine black line. The underside of the larva is pinkish-brown. Abdominal segments have a transverse band of six blue dots with each dot ringed by a fine black line (much thinner than those on larvae of the spicebush swallowtail, Papilio troilus Linnaeus. One dot on each side is beneath the lateral line. There is a pair of large tan false eyespots lined with black on the rear of the thorax. The eyespots have a large black center and a white "false reflection" above. Larvae also have a smaller pair of tan spots at the front of the abdomen.

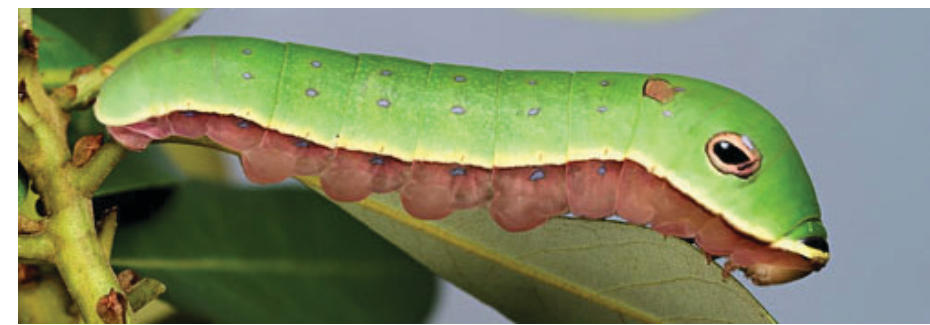

Figure 6. Palamedes swallowtail, Papilio palamedes (Drury), full-grown (5th instar) larva.

Credits: Donald W. Hall, UF/IFAS

Young larvae (instars 1-3) are tan to brown with a white middle (Figures 7 and 8). Second through fourth instars also have a pair of false eyespots on the thorax. The early instars (1-3) are similar in appearance to young larvae of the spicebush swallowtail except abdominal segments 8 and 9 (including the scoli [Figure 8]) are completely white. The mid-dorsal area of segment 8 and all of segment 9 is brown on young Papilio troilus. Also, the scoli of Papilio troilus on these segments are brown instead of white.

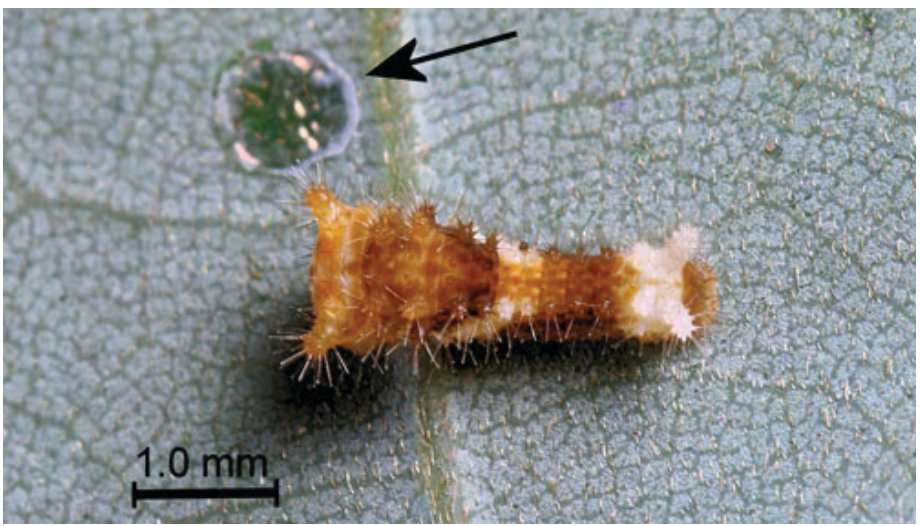

Figure 7. Palamedes swallowtail, Papilio palamedes (Drury), 1st instar and base of partially eaten egg shell (arrow).

Credits: Donald W. Hall, UF/IFAS

Fourth instars are similar in pattern to second and third instars, but the scoli on the ninth abdominal segment are reduced to small bumps (Figure 9 ).

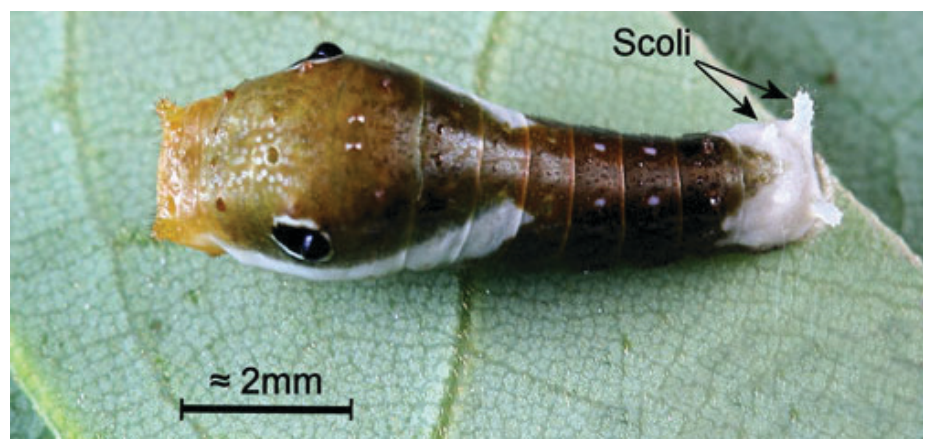

Figure 8. Palamedes swallowtail, Papilio palamedes (Drury), early instar larva (2nd or 3rd). Note white terminal segments and scoli.

Credits: Donald W. Hall, UF/IFAS

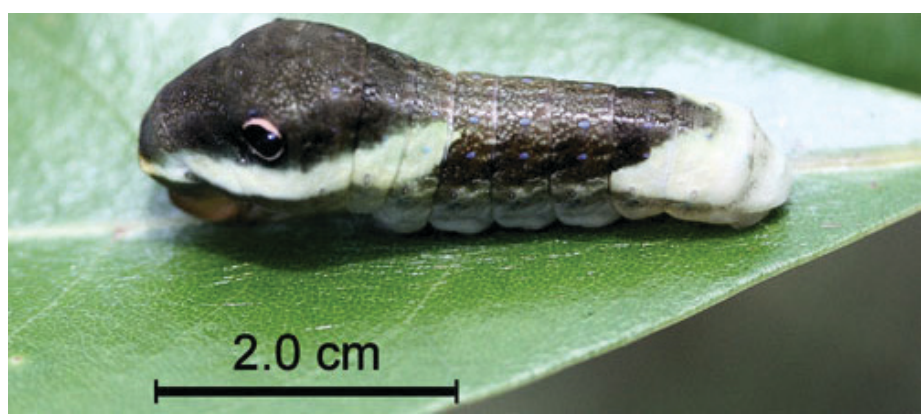

Figure 9. Palamedes swallowtail, Papilio palamedes (Drury), late fourth instar larva.

Credits: Donald W. Hall, UF/IFAS

\section{Pupae}

Pupae may be green or brown and have two short horns (Figure 10).

Scudder (1889) gave detailed descriptions of all stages including all five larval instars.

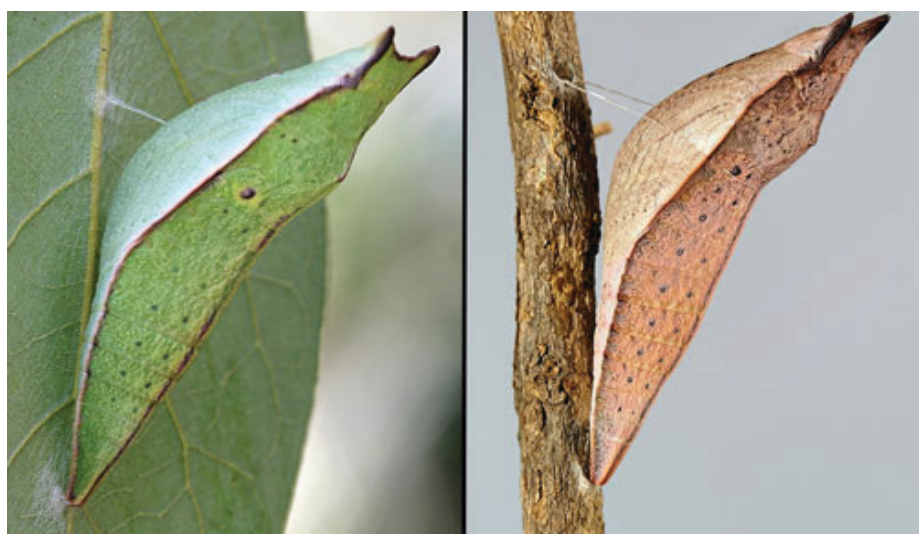

Figure 10. Palamedes swallowtail, Papilio palamedes (Drury), green and brown pupae.

Credits: Donald W. Hall, UF/IFAS

\section{Life Cycle}

There are two flights in Virginia (Opler and Krizek 1984; Scott 1986) and at least three flights in Florida (Minno et al. 2005). Males patrol wooded areas in search of females. During courtship, the female flies 1-2 feet above the ground, and the male flies 1-2 feet above her (Glassberg et al. 2000). 
Oviposition occurs near mid-day (Opler and Krizek 1984). Eggs are laid singly on the underside of new foliage of the host plants (see below) (Scriber 1996). Before pupation, full-grown larvae cease feeding and turn to a yellow color. These "prepupae" typically wander off the host plants to pupate (Minno et al. 2005). The "prepupae" retain the yellow color during the pupation process (Figure 11). Pupae are the overwintering stage (Cech and Tudor 1995; Minno and Minno 1999).

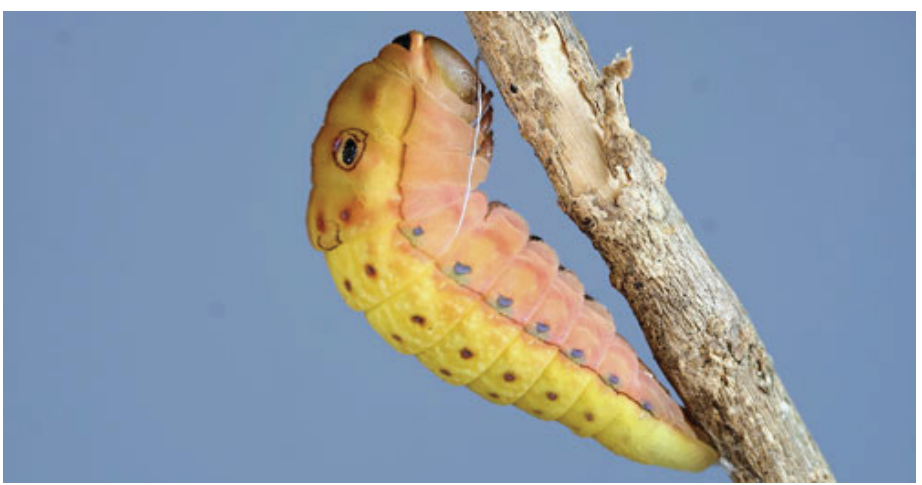

Figure 11. Palamedes swallowtail, Papilio palamedes (Drury), prepupa. Credits: Donald W. Hall, UF/IFAS

Within the last 24 hours before adult emergence, the preadult gradually becomes visible through the transparent pupal cuticle (Figure 12).

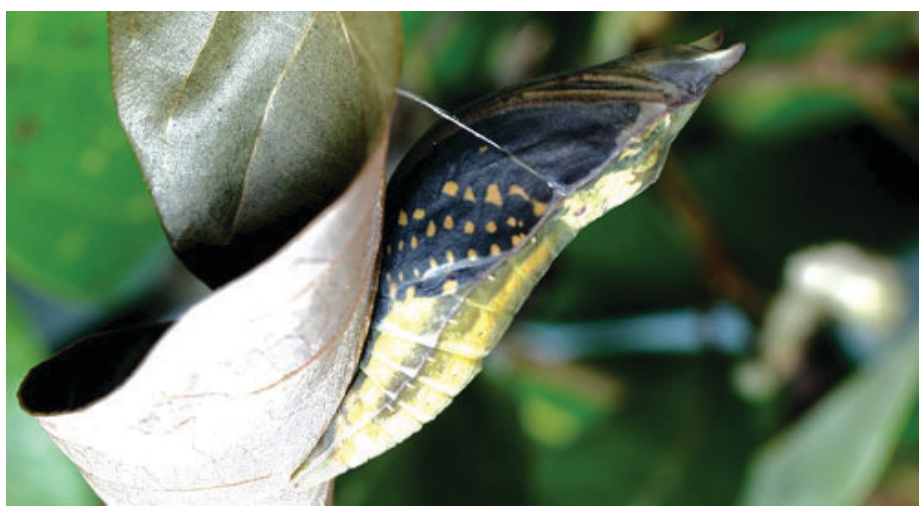

Figure 12. Palamedes swallowtail, Papilio palamedes (Drury), preadult. Credits: Donald W. Hall, UF/IFAS

\section{Host Plants}

Red bay, Persea borbonia var. borbonia (L.), and swamp bay, Persea palustris (Raf.) Sarg. (Lauraceae) are the primary host plants (Scriber and Margraf 2005). These species may be differentiated by the following characteristics:

1. Hairs on the stems and leaves of Persea borbonia are closely appressed while those of Persea palustris are crinkly - giving the leaves and stems a fuzzy feel (Proenza and Andreu 2013) (Figure 13).

2. Peduncles (stalks of flowers, inflorescences or fruits) of Persea borbonia are equal to or shorter than the subtending (below and close to) leaf petioles while those of Persea palustris are longer than the subtending petioles (Flora of North America undated) (Figure 14).

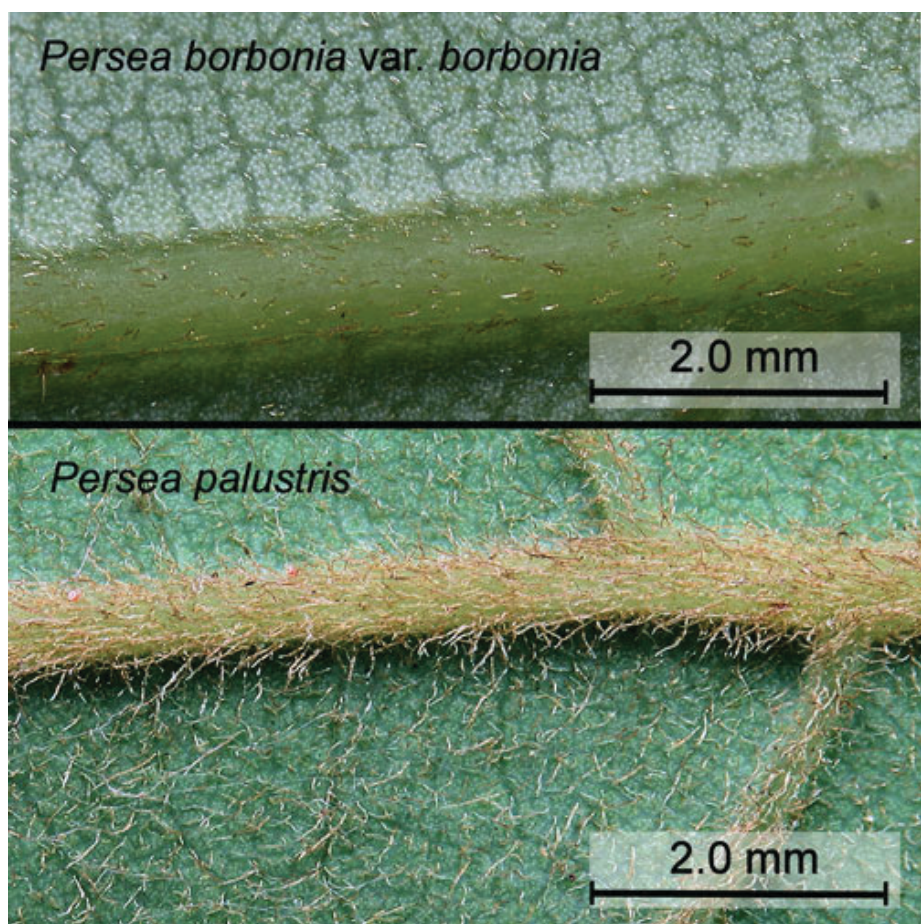

Figure 13. Leaf hairs of red bay, Persea borbonia var. borbonia (L.), and swamp bay, Persea palustris (Raf.) Sarg.

Credits: Donald W. Hall, UF/IFAS

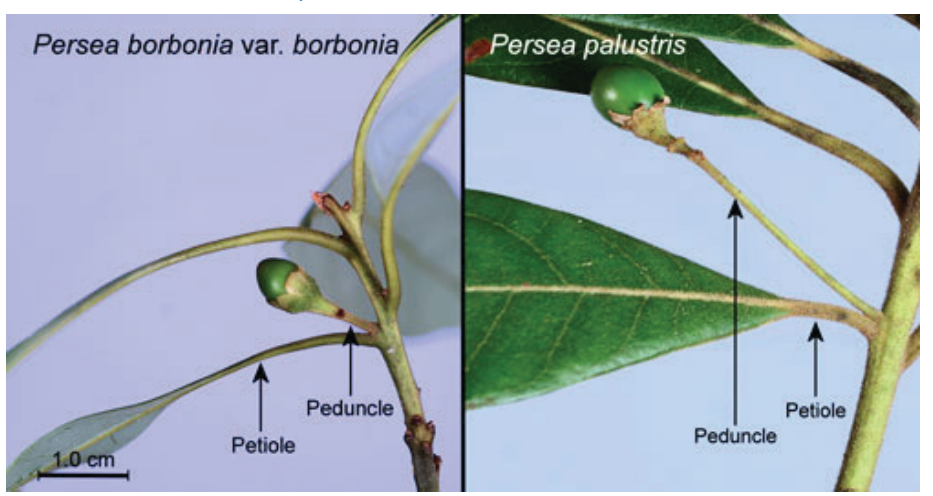

Figure 14. Peduncles and subtending petioles of red bay, Persea borbonia var. borbonia (L.), and swamp bay, Persea palustris (Raf.) Sarg. Credits: Donald W. Hall, UF/IFAS

Although Papilio palamedes larvae are capable of developing normally on silk bay (Persea borbonia var. humilis

[Nash] L.E. Kopp), a plant of scrub habitats, they have not been reported on it-possibly a result of habit preference or oviposition preference of females (Scriber and Margraf 2005).

All of our native species of Lauraceae are now threatened by laurel wilt disease. Laurel wilt is caused by Raffaelea lauricola T.C. Harr., Fraedrich and Aghayeva, a fungal symbiont of the red bay ambrosia beetle, Xyleborus glabratus Eichhoff. The red bay ambrosia beetle was first detected near 
Savannah, Georgia in 2002 (Fraedrich et al. 2008; Mayfield 2007) and is believed to have been introduced from Southeast Asia in the wood of shipping crates (Mayfield 2008).

Laurel wilt infection results in blockage of the xylem and fairly rapid death of red bays (Figure 15). It is estimated that laurel wilt has killed over 300 million red bay trees (Hughes et al. 2017).

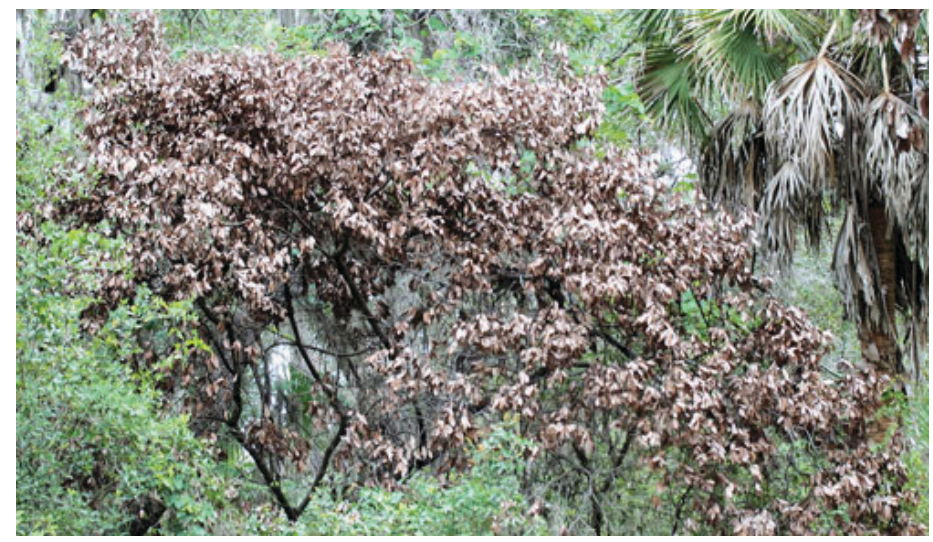

Figure 15. Red bays, Persea borbonia var. borbonia (L.), killed by laurel wilt.

Credits: Donald W. Hall, UF/IFAS (Shell Mound, Cedar Key, FL)

It is uncertain what effect the loss of all of these trees will have on Palamedes swallowtail populations. There is currently regrowth from the stumps of infected red bay trees, and Palamedes swallowtails are thriving on this new growth (Chupp and Battaglia 2014). Selection of resistant red bays for reforestation is the most promising approach to management of laurel wilt (Hulcr and Stelinski 2017). There is evidence for existence of some resistant trees (Hughes 2013), and research is being conducted to identify resistant individuals (Hughes et al. 2015).

The exotic (and invasive) camphortree, Cinnamomum camphora (L.) J. Presl., has shown some degree of resistance to laurel wilt. Chupp and Battaglia (2014) looked at possible host-shifting by Palamedes swallowtails from red bay to camphortree. Palamedes larvae will feed and develop on camphortree foliage. Unfortunately, females will not normally oviposit on it.

Species of other Lauraceae genera (e.g., Sassafras albidum [Nutt.] Nees, and Lindera benzoin [L.]) have been listed as occasional hosts in some of the older literature (e.g., Harris 1972; Klots 1951; Scott 1986; Tyler 1975). Larvae will feed on these and other species of Lauraceae in captivity (Brooks 1962), but adults are reluctant to lay eggs on them even when caged with the plants (Brooks 1962; Lederhouse et al. 1992). It is possible that some of the records on other Lauraceae species may have been due to mistaken identification of spicebush swallowtail (Papilio troilus L.) larvae as Palamedes swallowtail larvae. The distribution of Papilio palamedes closely coincides to the distribution of its Persea hosts (Cech and Tudor 2005; Chupp and Battaglia 2014; Lederhouse et al. 1992).

Sweet bay, Magnolia virginiana L. (Magnoliaceae), is also listed as a host in most of the older butterfly books (e.g., Holland 1949, Harris 1972, Klots 1951, Opler and Krizek 1984, Tyler et al. 1994, Plate 93 caption), but females will not oviposit on it (Brooks 1962), and larvae refused to eat it in laboratory studies (Brooks 1962; Scriber et al. 2000). In fact, chemicals extracted from Magnolia virginiana are toxic to first instar Palamedes swallowtail larvae (Nitao et al. 1992). Erroneous listings of Magnolia virginiana as a host date back to a watercolor painting by John Abbot of the Palamedes swallowtail life cycle on "Magnolia glauca" (now Magnolia virginana) (Figure 16) mentioned by Scudder (1889 [p. 1850]) (see Calhoun 2007). Calhoun (2017) gives a fascinating discussion of the history of this host plant error.

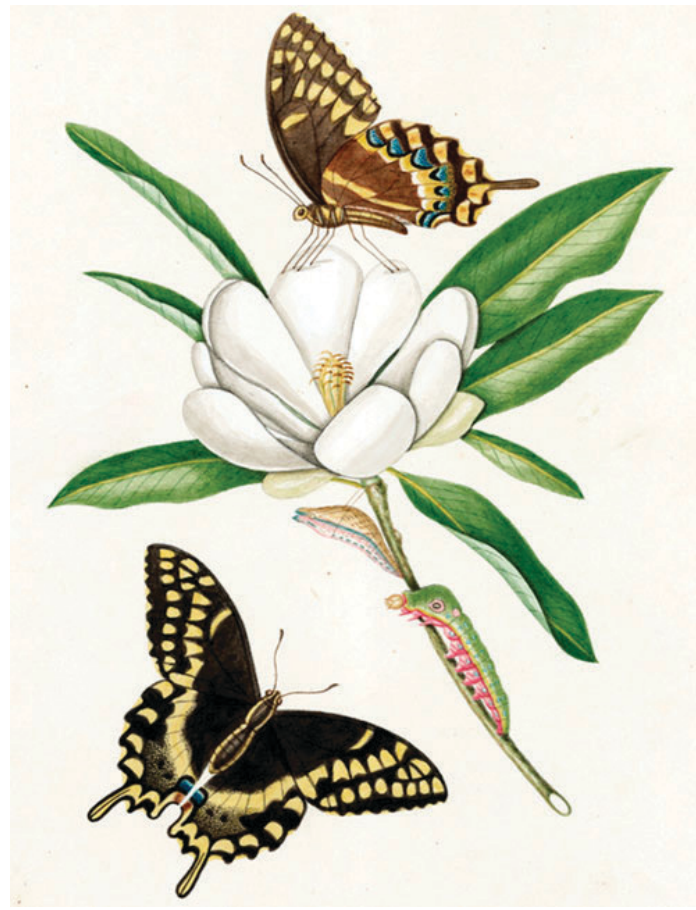

Figure 16. Watercolor painting by John Abbot (about 1816-1818) of life stages of Papilio palamedes (Drury) incorrectly on Magnolia virginiana $\mathrm{L}$.

Credits: Digital image provided by John Calhoun; original painting at the Alexander Turnbull Library, Wellington, New Zealand

Magnolia virginiana and Persea bays (particularly Persea borbonia) are commonly mistaken for each other, and this may have resulted in some of the erroneous host records for Papilio palamedes. Persea species can often be recognized by the characteristic leaf galls of the red bay psyllid, Trioza magnoliae (Ashmead) (Figure 17), which are usually present. There are no reliable records of Trioza magnoliae 
from Magnolia virginiana (Mead 1967). Therefore, it is obvious from the specific epithet "magnoliae" that Ashmead confused Persea borbonia and Magnolia virginiana.

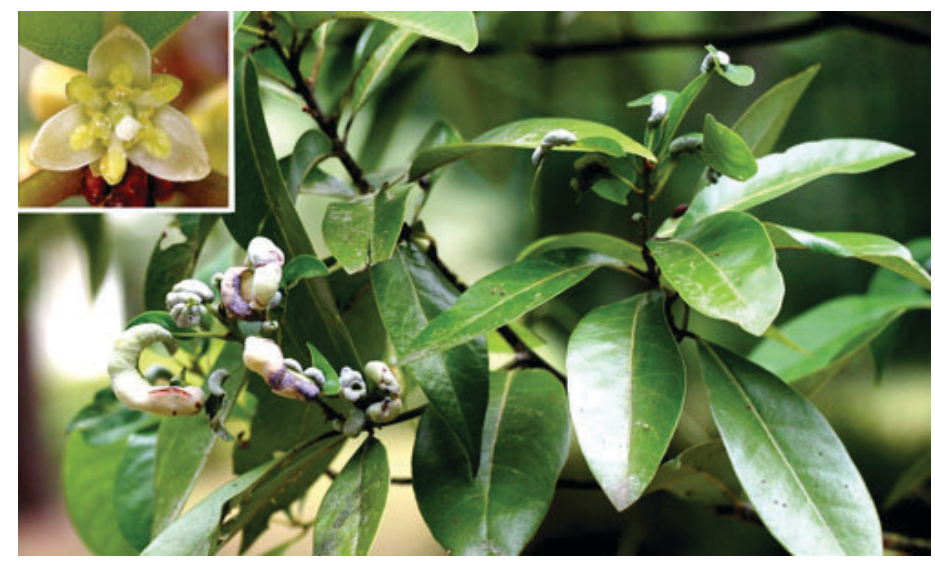

Figure 17. Red bay, Persea borbonia var. borbonia (L.), with galls of the red bay psyllid, Trioza magnoliae (Ashmead). Inset: Persea borbonia flower.

Credits: Donald W. Hall, UF/IFAS

The leaves of sweet bay (Magnolia virginiana) and red bay (Persea borbonia) are similar in appearance with darkgreen, glossy upper surfaces and glaucous undersides, and they sometimes grow side-by-side in moist areas. They can be differentiated with certainty by the stipular scar that completely surrounds the twig in Magnolia virginiana but is lacking in Persea species (Figure 18).
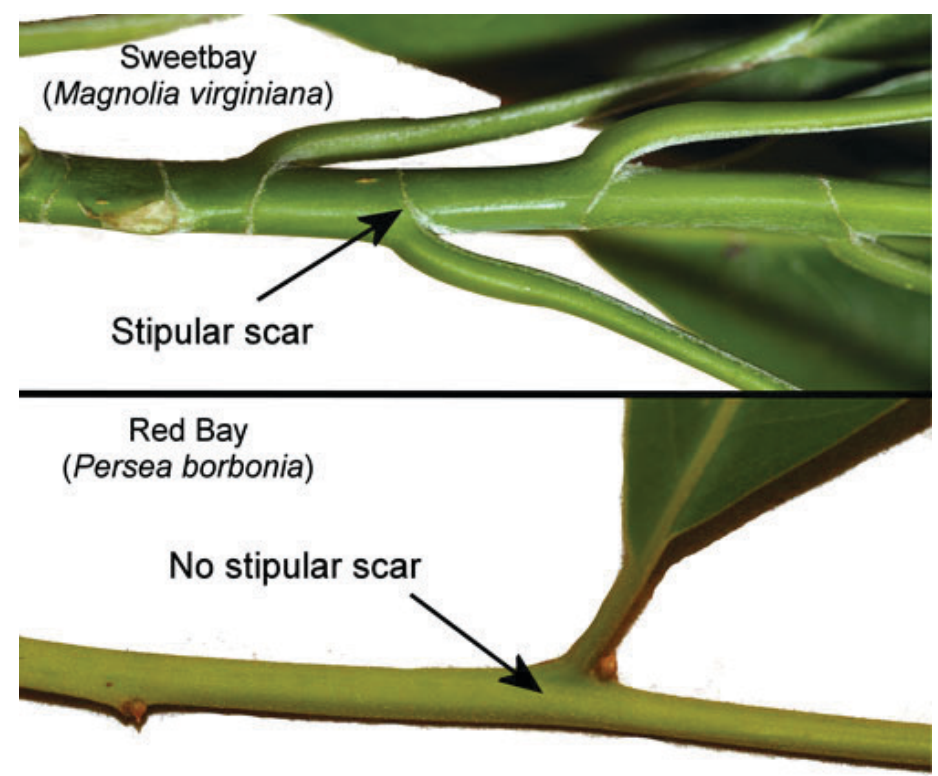

Figure 18. Stems of red bay, Persea borbonia var. borbonia (L.), and sweet bay, Magnolia virginiana L. showing stipular scars of Magnolia virginiana.

Credits: Donald W. Hall, UF/IFAS

Also, the flowers and fruits are quite different. The flowers of Persea borbonia are small (about $5 \mathrm{~mm}$ in diameter) and greenish-white (Figure 17 [inset]), and the fruits are berry-like drupes (about $1 \mathrm{~cm}$ in diameter) (Figure 14). The flowers of Magnolia virginiana are much larger (about $6 \mathrm{~cm}$ in diameter) and yellowish-white in color, and the fruits are cone-like and open to release red seeds that hang by threads (Figure 19). Detailed descriptions and drawings of both species are given by Zomlefer (1994).

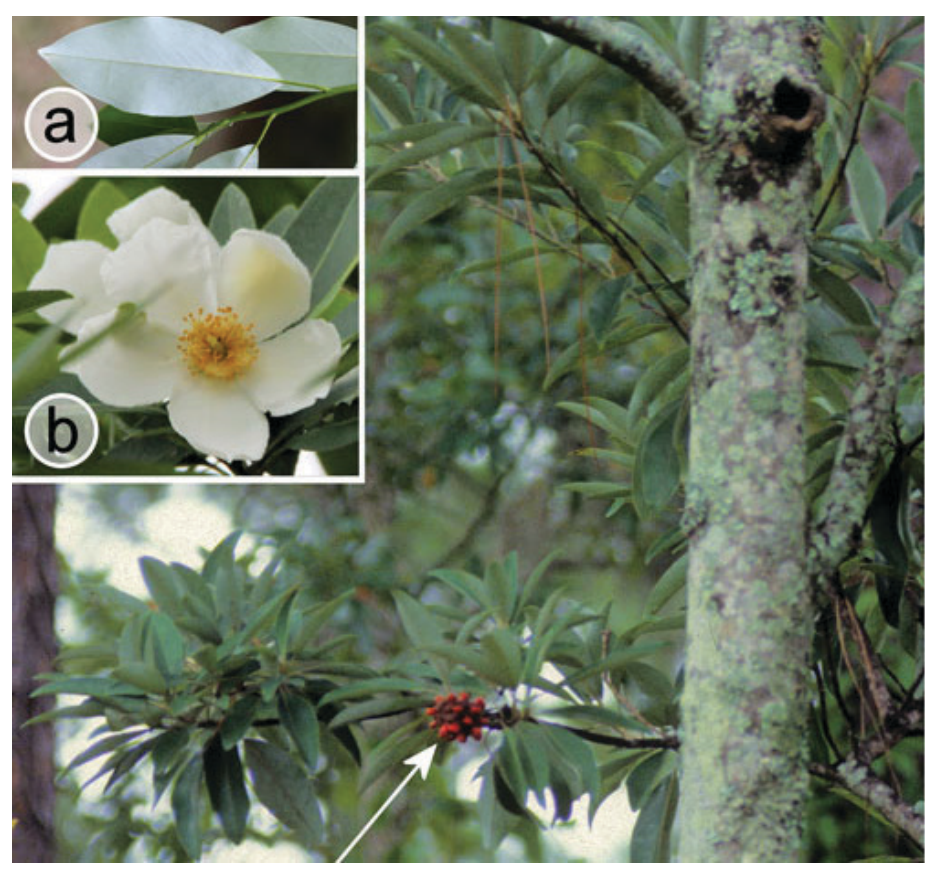

Figure 19. Sweet bay, Magnolia virginiana L. Arrow: fruit with seeds. Insets: a) foliage b) flower. Magnolia virginiana was erroneously reported as a larval host for the Palamedes swallowtail, Papilio palamedes (Drury).

Credits: Donald W. Hall, UF/IFAS

Some of the erroneous host records of Palamedes swallowtail larvae on Magnolia virginiana may result from confusion with the similar larvae of the closely-related tiger swallowtail (Papilio glaucus L.) which commonly uses Magnolia virginiana as a host.

\section{Adult Behavior}

Adults (predominantly males) sip moisture from mud (Opler and Krizek 1984) - probably for sodium (Arms et al. 1974). Adults of both sexes sip nectar from flowers. Coastal sweet pepperbush (Clethra alnifolia L.), pickerelweed (Pontederia cordata L.), and thistles (Cirsium spp.) are reported to be particularly attractive as nectar sources (Opler and Krizek 1984; Tyler 1975). Palamedes swallowtails are considered the primary pollinators of sandhill thistle (Cirsium repandum Michaux) (Theis and Raguso 2005) and orange-fringed orchid (Platanthera ciliaris (L.) Lindl.) (Chupp et al. 2015).

Many plants are valuable as nectar sources for Palamedes swallowtails. Minno and Minno (1999) have extensive lists of both native and exotic nectar plants for butterflies. Most states have native plant societies that are valuable sources 
of information on native plants and many also hold native plant sales. For a list and contact information for native plant societies, see the American Horticultural Society's website. For Florida and the Deep South, the Florida Wildflowers Growers Cooperative is an excellent source of information and has wildflower seeds for purchase.

\section{Natural Enemies}

\section{Predators}

Scriber et al (1998) reported the following spiders as predators of Palamedes swallowtail adults: Argiope spp., Trichonephila clavipes (L.), and an unidentified species of crab spider. Adult Palamedes are also palatable to birds (Brower 1958). It is probable that both larvae and adults are eaten by a variety of vertebrate and insect predators.

\section{Parasitoids}

There are at least two hymenopterous parasitoids of Papilio palamedes:

- Pteromalus vanessae Howard (Krombein et al. 1979)

- Trogus pennator (Fabricius) (Wahl and Sime 2006)

\section{Defenses}

\section{Concealment and Camouflage}

Early instar caterpillars do not cut and fold leaves to make a shelter as does Papilio troilus (Minno et al. 2005; Scudder 1889), but older larvae may spin silk mats on leaves that cause the leaves to curl upward-partially concealing the larvae (Scott 1986) (Figure 20).

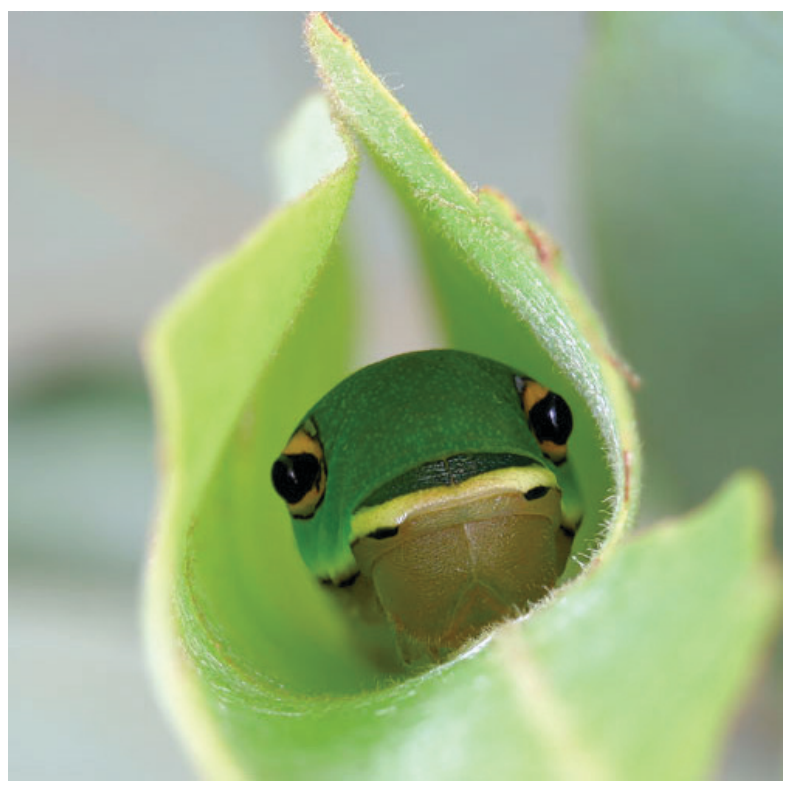

Figure 20. Palamedes swallowtail, Papilio palamedes (Drury), 5th instar larva on curled leaf.

Credits: Donald W. Hall, UF/IFAS
The yellow coloration of prepupae (Figure 9) blends with leaf litter and probably makes them less visible to predators while they are wandering to find pupation sites.

\section{Mimicry}

Early instar larvae resemble bird or lizard droppings (Figure 21).

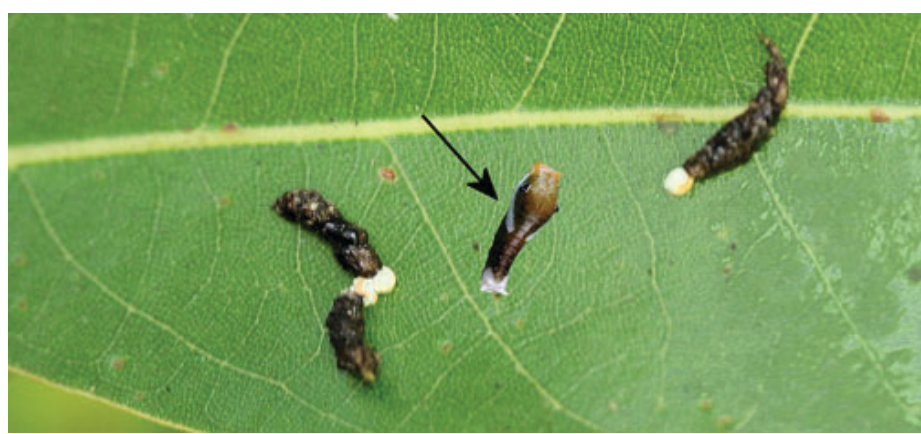

Figure 21. Palamedes swallowtail, Papilio palamedes (Drury), early instar larva (arrow) digitally pasted into photo with bird or lizard (probably lizard) droppings.

Credits: Donald W. Hall, UF/IFAS

Last instar larvae with their swollen thoraxes and false eyes are probably green snake or tree frog mimics (Lederhouse 1990) (Figure 22).

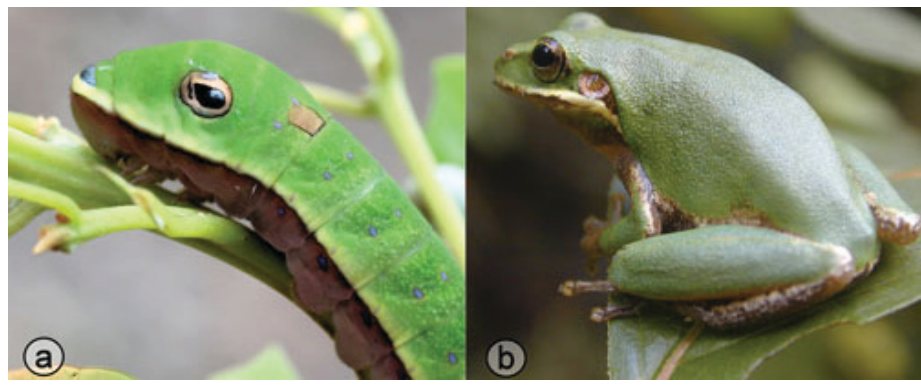

Figure 22. Palamedes swallowtail, Papilio palamedes (Drury), 5th instar larva (left) and squirrel tree frog, Hyla squirella Bosc (right).

Credits: a) Donald W. Hall, UF/IFAS; b) William Barichivich, US Geological Survey

While females of the other black-colored swallowtails ( $\mathrm{Pa}$ pilio troilus [L.], Papilio polyxenes Fabricius, and the black morph females of Papilio glaucus [L.]) are believed to be Batesian (edible) mimics of the (distasteful or poisonous) pipevine swallowtail, Battus philenor (L.) (Brower 1958; Brower and Brower 1968; Poulton 1909), the Palamedes swallowtail does not appear to be mimetic (Brower 1958).

\section{Osmeteria}

All North American swallowtail larvae have eversible (capable of being everted or turned inside out) horn-like organs behind the head known as osmeteria. The osmeteria of Palamedes swallowtail larvae are bright yellow-orange in all larval instars. When threatened, larvae rear up, extrude the osmeterium, and attempt to smear the potential predator with a chemical repellent (Figure 23). The osmeterial 
secretion of fifth instars is composed primarily of isobutyric and 2-methylbutyric acids (Eisner et al. 1970; Eisner et al. 2005). Osmeterial secretions of earlier instars are probably composed primarily of terpenes (Ômura et al. 2006).

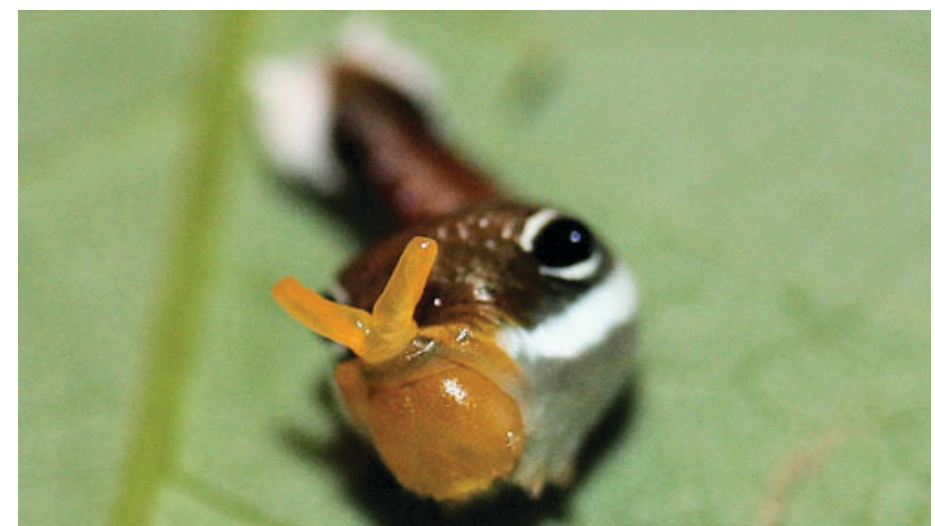

Figure 23. Palamedes swallowtail, Papilio palamedes (Drury), middle instar larva with osmeterium extruded. Credits: Donald W. Hall, UF/IFAS

\section{Acknowledgements}

The author would like to acknowledge Howard Frank and Marc Minno for reviewing this article and offering helpful suggestions. The author also expresses appreciation to John Calhoun for providing the digital image of John Abbot's watercolor (Figure 15) and William Barichivich for permission to use his photograph of the squirrel tree frog (Figure 20).

\section{Selected References}

Arms K, Feeny P, Lederhouse RC. 1974. "Sodium: Stimulus for puddling behavior by tiger swallowtail butterflies, Papilio glaucus." Science 185: 372-374.

Borror DJ. 1960. Dictionary of Word Roots and Combining Forms. Palo Alto, CA: Mayfield Publishing Company.

Brooks JC. 1962. "Food plants of Papilio palamedes in Georgia.” Journal of the Lepidopterists' Society 16(3): 198.

Brower JVZ. 1958. "Experimental studies of mimicry in some North American butterflies. 2. Battus philenor and Papilio troilus, P. polyxenes and P. glaucus." Evolution 12(2): 123-136.

Brower LP, Brower JVZ. 1962. "The relative abundance of model and mimic butterflies in natural populations of the Battus philenor mimicry complex." Ecology 43: 154-158.

Butterflies and Moths of North America. 2017. https:// www.butterfliesandmoths.org/species/Papilio-palamedes (November2017)
Calhoun JV. 2007. “John Abbot's butterfly drawings for William Swainson, including general comments about Abbot's artistic methods and written observations." Journal of the Lepidopterists' Society 61(1): 1-20.

Calhoun JV. 2017. "Why sweet bay was reported as a food plant of Papilio palamedes (Papilionidae)." Southern Lepidopterists' News 39(2):144-146.

Cech R, Tudor G. 2005. Butterflies of the East Coast. Princeton, NJ: Princeton University Press.

Chupp AD, Battaglia LL. 2014. "Potential for host shifting in Papilio palamedes following invasion of laurel wilt disease." Biological Invasions 16: 2639-2651.

Chupp AD, Battaglia LL, Schauber EM, Sipes SD. 2015. Orchid-pollinator interactions and potential vulnerability to biological invasion. AoB Plants Vol.7: Article number: plv099. 9pp. Oxford England: Oxford University Press.

Drury D. 1770-1782. Illustrations of natural history, wherein are exhibited upwards of two hundred and forty figures of exotic insects, according to their different genera. B. White, London. (palamedes description and figures: pp. 37-38, Plate XIX) (November 2017)

Eisner T, Eisner M, Siegler M. 2005. Chap. 64. Class Insecta, Order Lepidoptera, Family Papilionidae, Eurytides marcellus, the zebra swallowtail butterfly. pp. 297-303. In: Secret Weapons: Defenses of Insects, Spiders, Scorpions, and Other Many-legged Creatures. Harvard University Press. Cambridge, Massachusetts. 372 pp.

Eisner T, Pliske TE, Ikeda M, Owen DF, Vázquez L, Pérez H, Franclemont JG, Meinwald J. 1970. "Defense mechanisms of arthropods. 27. Osmeterial secretions of papilionid caterpillars (Baronia, Papilio, Eurytides)." Annals of the Entomological Society of America 63(3): 914-915.

Flora of North America. Undated. Vol. 3. http://www. efloras.org/florataxon.aspx?flora_id=1\&taxon_id=124627 (November 2017)

Fraedrich SW, Harrington TC, Rabaglia RJ, Ulyshen MD, Mayfield AE, Hanula JL, Eickwort JM, Miller DR. 2008. "A fungal symbiont of the redbay ambrosia beetle causes a lethal wilt in redbay and other Lauraceae in the southeastern United States." Plant Disease 92: 215-224.

Glassberg J, Minno MC, Calhoun JV. 2000. Butterflies Through Binoculars: A Field, Finding, and Gardening Guide 
to Butterflies in Florida. New York, NY: Oxford University Press.

Hancock DL. 1983. "Classification of the Papilionidae (Lepidoptera): A phylogenetic approach.” Smithersia 2: $1-48$.

Harris L. Jr. 1972. Butterflies of Georgia. Norman, OK: University of Oklahoma Press.

Heppner JB. 2003. Lepidoptera of Florida. Part 1. Introduction and Catalog. Volume 17 of Arthropods of Florida and Neighboring Land Areas. Division of Plant Industry. Florida Department of Agriculture and Consumer Services. Gainesville, Florida. 670 pp.

Holland WJ. 1949. The Butterfly Book. Doubleday. Garden City, New York. 424 pp. +77 plates. (Revised edition of original 1898 edition)

Hughes MA. 2013. The evaluation of natural resistance to laurel wilt disease in redbay (Persea borbonia). $\mathrm{PhD}$ Dissertation, University of Florida. Gainesville, Florida.

Hughes MA, Riggins JJ, Koch FH, Cognato AI, Anderson C, Formby JP, Dreaden TJ, Ploetz, Smith JA. 2017. "No rest for the laurels: symbiotic invaders cause unprecedented damage to southern USA forests." Biological Invasions.

Hughes MA, Smith J, Ploetz R, Kendra P, Mayfield AIII, et al. 2015. "Recovery plan for laurel wilt on redbay and other forest species caused by Raffaelea lauricola and disseminated by Xyleborus glabratus." Plant Health Progress $16: 17-210$

Hulcr J, Stelinski LL. 2017. "The Ambrosia symbiosis: from evolutionary ecology to practical management." Annual Review of Entomology 62: 285-303.

Klots AB. 1951. A Field Guide to the Butterflies. Boston, MA: Houghton Mifflin.

Krombein KV, Hurd Jr. PD, Smith DR, Burks BD. 1979. Catalog of Hymenoptera in America North of Mexico. Volume 1. Symphyta and Apocrita (Parasitica). Washington, DC: Smithsonian Institution Press.

Lederhouse RC. 1990. Avoiding the hunt: Primary defenses of lepidopteran caterpillars. pp. 175-189. In Evans DL, Schmidt JO. (eds). Insect Defenses: Adaptive Mechanisms and Strategies of Prey and Predators. Albany, NY: State University of New York Press.
Lederhouse RC, Ayres MP, Nitao JK, Scriber JM. 1992. "Differential use of lauraceous hosts by swallowtail butterflies, Papilio troilus and P. palamedes (Papilionidae)." OIKOS 63: 244-252.

Mayfield AE III. 2007. "Laurel wilt: A serious threat to redbay and other related plants." The Palmetto 24(3): 8-11.

Mayfield AE III. 2008. "Laurel wilt, forest and shade tree pests leaflet No. 13." Gainesville, FL: Florida Department of Agriculture and Consumer Services, Division of Forestry.

Mead FW. (1963). A psyllid, Trioza magnoliae (Ashmead). FDACS-Division of Plant Industry. (November 2017).

Miller JS. 1987. "Phylogenetic studies in the Papilioninae (Lepidoptera: Papilionidae)." Bulletin of the American Museum of Natural History 186: 365-512.

Minno MC, Butler JF, Hall DW. 2005. Florida Butterfly Caterpillars and their Host Plants. Gainesville, FL: University Press of Florida.

Minno MC, Emmel TC. 1993. Butterflies of the Florida Keys. Gainesville, FL: Scientific Publishers.

Minno MC, Minno M. 1999. Florida Butterfly Gardening. Gainesville, FL: University Press of Florida.

Nitao JK, Johnson KS, Scriber JM, Nair MG. 1992. “Magnolia virginiana neolignan compounds as chemical barriers to swallowtail butterfly host use." Journal of Chemical Ecology 18(9): 1661-1671.

Ômura H, Honda K, Feeny P. 2006. "From terpenoids to aliphatic acids: further evidence for late-instar switch in osmeterial defense as a characteristic trait of swallowtail butterflies in the tribe Papilionini." Journal of Chemical Ecology 32: 1999-2012.

Opler PA, Krizek GO. 1984. Butterflies East of the Great Plains. Baltimore, MD: The Johns Hopkins University Press.

Opler PA, Malikul V. 1998. A Field Guide to Eastern Butterflies. Peterson Field Guides. New York, NY: Houghton Mifflin Company.

Pelham JP. 2008. A catalogue of the butterflies of the United States and Canada with a complete bibliography of the descriptive and systematic literature. Journal of Research on the Lepidoptera 40:xiv + 658 pp. 
Poulton EB. 1909. "Mimicry in butterflies of North America." Annals of the Entomological Society of America 11(4): 203-242.

Proenza L, Andreu M. 2013. Key to Common Bays. FOR311. Gainesville: University of Florida Institute of Food and Agricultural Sciences. (Accessed November 15, 2017)

Scott JA. 1986. The Butterflies of North America. Stanford, CA: Stanford University Press.

Scriber JM. 1996. "Tiger tales: Natural history of native North American swallowtails." American Entomologist 42: $19-32$.

Scriber JM, Deering MD, Francke LN, Wehling WF, Lederhouse RC. 1998. Notes on swallowtail population dynamics of three Papilio species in south-central Florida (Lepidoptera: Papilionidae). Holarctic Lepidoptera 5: 53-62. (November 2017)

Scriber JM, Margraf N. 2000. Suitability of four families of Florida "Bay" species for Papilio palamedes and P. glaucus (Papilionidae). Journal of the Lepidopterists' Society 54(4): 131-136.

Scriber JM, Margraf N, Wells T. 2005. "Suitability of Florida red bay and silk bay for Papilio palamedes butterfly larvae (Lepidoptera: Papilionidae)." Holarctic Lepidoptera 10(1-2): 49-51.

Scudder SH. 1889. The butterflies of the eastern United States and Canada: With special reference to New England. Vol. 3 (Not found in New England). pp. 1775-1958. 89 plates +3 maps. (Euphoeades palamedes).

Theis N, Raguso RA. 2005. "The effect of pollination on floral fragrance in thistles." Journal of Chemical Ecology 31(11): 2581-2600.

Tyler HA. 1975. The Swallowtail Butterflies of North America. Healdsburg, CA: Naturegraph Publishers.

Tyler HA, Brown KS Jr, Wilson KH. 1994. Swallowtail Butterflies of the Americas. Gainesville, FL: Scientific Publishers.

Wahl DB, Sime KR. 2006. "A revision of the genus Trogus (Hymenoptera: Ichneumonidae, Ichneumoninae)." Systematic Entomology 31: 584-610.

Warren AD, Davis KJ, Stangeland EM, Pelham JP, Willmott KR, Grishin NV. 2016. Butterflies of America. (http:// butterfliesofamerica.com/papilio_p_palamedes.htm) (November 2017)

Zomlefer WB. 1994. Guide to Flowering Plant Families. Chapel Hill, NC: The University of North Carolina Press. 